\title{
The Traditional Mechanisms of Conflict Resolution \& Peace Building in Darfur; From an Anthropological Perspective
}

\author{
Isam Mohamed Ibrahim \\ PhD, sociology and anthropology, \\ University of al - fashir, Darfur, Sudan. \\ issamwadai@yahoo.co.uk
}

\section{Doi:10.5901/mjss.2013.v4n9p132}

\begin{abstract}
The study assesses the Volunteering \& social interaction between components of Darfur that remain active and peaceful as long as these mechanisms remain active. Historically, Darfur society enjoys accumulative and stratified stage of norms and traditions that processed over experiments and experience of generation throughout centuries and converged to unrecorded law which all subjected to it. Norms and traditions were transformed orally from one generation to another. The research found that many indigenous affected by conflicts resolution in Darfur, i.e. the native administration, ajaweed council (al-judia), mechanisms of farmer, herder conflict the rakuba and so on. And on other side their mechanisms for peace building like: alNafeir, Social relations, Hunting group, al-fazza, al-darra, local markets, life cycle event, folke literature ...etc. The study concludes with recommendations to for promoting these mechanisms in order to contribute efforts aimed at identifying ways of achieving sustained peace in Darfur.
\end{abstract}

Keywords: Traditional, Mechanisms, Conflict, Peace, Darfur.

\section{Methodology and Structure:}

This study is based mainly on primary date from the field. The data was collected in al-Fashir; north Darfur during (20082009). This data was collected through conducting individual and group. Interviews the sector of our people is Ajaweed, ethnic leaders, native Administration personally and other data is secondary data which we collected from books, articles, published and unpublished theses.

This study is structured as follows: The socio-cultural context in Darfur conflicts mechanisms, peace building mechanisms, the change which happened in this mechanisms, how can developing this mechanisms at last we outline the conclusions and recommendations of the research.

\section{Introduction}

\subsection{Description of Community/Region/People:}

Darfur region is located in the extreme west of the Sudan between latitudes 20 and 10 north; and longitudes 22 - 27 west. The size of Darfur is approximately 510,000 square KM. Darfur population is estimated at 5 million (1995 census) and current at 6 million composed of 170 tribes and ethnic groups, speaking more than 24 local dialects. Arabic represents the lingua franca for these groups. Darfur has the second highest population densities in the Sudan as coopered to the central region. The population of Darfur represents 23\% of north Sudan (Ibrahim, 2006).

The climate of Darfur is semi-desert and desert in the north, poor savannah in the central areas and rich savannah in the southern part of Darfur. The vast area with diverse climate have endowed the region with many natural resources such as fertile land in the central and southern part, but it has increased desertification in the northern part rendered the competition between farmers and pastoralists on scarce resources (Lompen, 1950).

The population as such is divided into traditional farmers, agro-pastorals and pastoral groups. The camel herders lives in the arid northern part, these are namely northern Rezaigat and Zayadiya who are from Arab roots, the Meidob and the Zaghawa who are from African roots. The central area is habited by indigenous farmers and agro-pastorals citizens (mainly Fur, Tongur, Barti, Masalit and Bergit) and the southern rich savannah is habited by Arab tribes such as Rezaigat, Habbania, Taaisha, Bani Halba and Falatta (Michel More, 1932). 
Darfur in contrast to other regions of Sudan has rich cultural and ethnic diversity, hundreds of Africans and Arab tribes and ethnic groups have lived together for centuries. The majority of Darfur's population lives in communities guided by the tribe and clan. Islam is the only religion among the region for both Arabs and Africans (Ibrahim, 2004).

\subsection{Background}

The Darfurian cultural consciousness is full of principles that encourage individuals to live in peace with others.

If we trace out life of an individual from the family to the big society, we find that in Darfur, children are born in the hands of a mid-wife called at any time to provide humanitarian service for free. What she receives from the parents of the newly born is a gift not a wage. Then, the child is guarded by all the surrounding individuals until he grows to the age of circumcision or excision which is also done for free. When children are circumcised, their colleagues and mates collect hens from throughout the village not necessary from relatives or friends until the circumcised are cured. Playground also provides a good chance for children to play collective games where today's mates can become tomorrow's contestants.

The child then migrates to become a disciple of one of the sheihks who also offer instructions for free. The accommodation of these disciplines is provided by the inhabitants around the massik. When he reaches certain oversets (sharaffa) the neighboring community offers him her gifts and celebrates the occasion.

Marriage in Darfur is not only a family business. The family receives material support from neighbors and friends to meet the expenses of the wedding ceremony. In these ceremonies women prepare food and men build a house for the couple. These events are accompanied by dances and songs performed collectively and freely. This cooperative life continues until the one is dead where all people gather to bury him.

\section{Conflict resolution mechanisms}

\subsection{The Native Administration}

The British administration has first recognized and developed the tribal system, existing for centuries, by issuing legislations to suit their purposes, into administrative units in the head of each figures a Nazir, Malik, Sultan or Demingai. The succession is always by inheritance (O'Fahey 1977).

Restrict legislations are made to prevent tribes to move from their lands except in the emergencies; droughts, wars, epidemic diseases... provided that they return as the moment when the danger is over.

After the independence, this system has regressed gradually as new concepts about administration, state, individual rights, freedom of movement emerged. In addition, the smaller tribal groups rejected the rule of the bigger ones and started searching new forms of administration which caused conflicts that rapidly turned into war with all its political, social and cultural consequences.

A great portion of Darfur, notably the rural areas, has adopted the native administration system. The power hierarchy starts with the Sheikh at the village level. Group of sheikhs are under the authority of an Omda who is in turn, owes loyalty to the Nazir, Shartai or Malik.

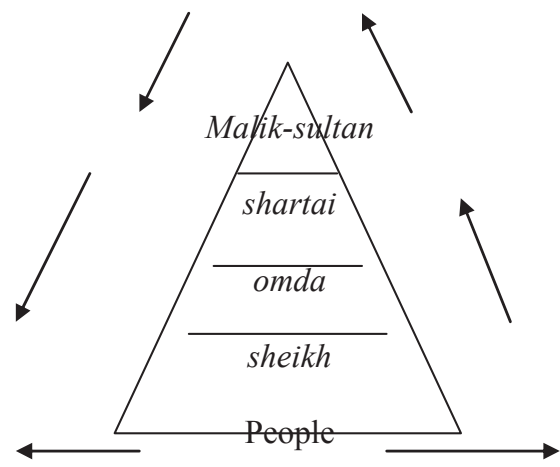

Shape 1. The native administration system in Darfur 
This division is not generalized in Darfur. In some areas it follows the same order but differ in the names. The top of the pyramid, for example, is sometimes called Sultan, or call him Nazir... while the bottom is called sheikh or farsha (Bathily,1977).

This type of authority is highly respected because it is deeply rooted in the mentality of the population.

\subsection{Ajaweed Council (al-Joudia)}

It is one of the most important social institutions in Darfur which is used to resolve conflicts. It is the ajaweed who resolve problems within the village, area and the towns. They are always the elderly people who have good reputation of wisdom and experience. The session of this council is also known as joudia. The informant Malik Rahamtalla Mahmoud tells "the joudia is a heritage in Darfur used to solve the little problems before they escalate into conflicts.... The term ajaweed is deriven from joudia which means a council for generosity and reconciliation. The ajawweed are those who lived for long time and learnt from fathers. The proverb says: the one who lived with his father knows the sayings of his grandfather. The joudia is called in wdai fashiriya, they say there are relations between Darfur and Chad".

This is confirmed by the informant Abdalla Ibrahim Teirab one of the notables of Darfur and a famous ajwadi: "ajaweed is driven from joud, the one who is in good wealth is the most generous. For example, if someone travels the ajwad pays for his family until he is back. If guests arrive, it is the ajwad who takes the charge. If there is dispute in farm boundaries, people say it won't be solved unless the ajaweed sit. What they say is convincing and obeyed by all. So it is called majlas alajaweed"

\subsubsection{Qualities of the ajaweed}

To be an ajwad to solve problems in Darfur one must have the following characteristics, as all informants confirm:

- long life experience

- age and reason

- good knowledge of peoples life and traditions

- Gain the trust of all.

- Knowledge and wisdom

- Patience

- Generosity

- Good negotiation abilities and democracy.

The joudia could, then, be defined as: mediation led by a group of people to end a conflict between individuals or groups. From this definition we can conclude that the ajaweed must enjoy a good knowledge of the traditions and the history of the area. The joudia in Darfur gained a status near to divinity. The one who rejects its rule must immediately be rejected by the society (Fadoul,2008).

The local courts of justices are one way or other types of joudias. In some cases even the formal courts of justice advice the protagonists to go back to their villages to let the ajaweed see the predicaments and if they fail they can come back to the court (Ibrahim,2007).

In this regard, the informant Idriss Albanani Adam Eltahir tells us "in Darfur the Joudia constitutes an important mechanism to solve problems among individuals, families, tribes... in villages and cities. The one who participates in the joudia is called ajwad. When the ajwad conmes to a joudia, he has no money to pay. He only has reasonable ideas to convince the parties of conflict to compromise until an ideal justice is reached. When he decides, his judgment is obeyed." And he continues "the joudia has its traditions and rites. It covers predicaments in land, livestock, farms, family problems.... Its judgment is accepted more than any verdict delivered by a formal court of justice".

The benefit of joudia goes beyond the range of the local traditional conflicts in Darfur to cover areas like reconciliation conferences held by the state. Aamir Adam Tobelharir affirms: "we, in local governments department, call on the ajaweed in case of conflicts on land between sedentary and nomads to help us solve the problems. We can say that the ajwaad who ruled for centuries exist and they can rule up to this moment."

\subsubsection{Description of the Ajaweed Council}

Joudias vary according to the type of conflict that, generally, we can classify them into two main categories:

- conflict tackled at the family or area level 
- Tribal conflicts tackled by the authorities in big conferences.

The traditional joudia is held either immediately or spontaneously after the disagreement takes place or after the ajaweed are invited by the parties of conflict. The council can be formed from a group of 3 to 9 members provided that they are accepted by both parties as neutral and credible. But generally, people make use of what is known as village angles (the sheikh or dimlij, the imam) in addition to the ajaweed of the village and sometimes the ajaweed of the neighboring villages. When it is in session, it can tackle cases like; injuries, killings, theft or robbery, land aggression, confrontations between nomads and sedentary, tribal conflicts, family troubles.

Since the entire population of Darfur is Muslim confession, the rules are driven from the Islamic jurisprudence but some pre-Islamic rites interfere from time to another.

Adam Idris Albanani describes the joudia saying: "as long as people live in the same place, conflicts normally. People in Darfur say that the Ajouad is a needle to sew the torn. In case the problem is not solved at the village level rather people seek for solution at an upper ajaweed level".

According to this study, the researcher can say that conflicts in Darfur are, generally, of two types. Conflict between sedentary and nomads and conflicts of competition over natural resources.

\subsection{Mechanisms of farmer-herder conflicts resolution}

Conflicts take place between individuals and communities from time to another notably for rain fed agricultural lands, fruit farms and Arabic gum concessions. There are also conflicts between farmers and herders on water resources but conflicts for land are the most prominent. There are traditions which solve these problems and these traditions are closely related to land use systems.

As it is mentioned earlier, land in Darfur is owned by tribes. Its ownership is not absolute; it is only to organize its use (O'Fahiy, 1977). The efficiency of these mechanisms is summed up in the following points.

3.3.1 Farm border conflicts (kleikab): The border between two farms is always marked by non-cultivated space, water run, trees...etc. Conflict arise when one of the neighbors deform these borders to expand his farm. When this happen the other party can complain to the land sheikh who is supposed to know the borders. When he fails to identify the border he can make use of ajaweed who in turn call on the local population to help. Generally people accept he verdict of the ajaweed. If a solution is not reached, the conflict will be transferred to be viewed by an upper level of ajaweed or authority (Ibrahim, 2002).

3.3.2 Arabic gum concessions conflicts: Gum forests are inherited from generation to generation. When a conflict on border or possession arises the same steps are followed as in the previous type of conflict.

Hakoura property conflict: When there is a conflict on the possession of a hakoura, the parties must show the documents. If the documents are lost, witnesses are called. Boarders in Darfur are generally marked by a tree, water pond, valley, rock or mountain. In addition, people make what's known as boarder holes; a hole of one I two meters and many meters deep to be filled by tar, raw iron and millet ..... When digging and filling these holes all inhabitants must attend to witness that this a boarder point. The successive generations come from time to time to check that it's intact. When a conflict arises witnesses come and dig to check it out.

Idris Albanany continues: (after the Ajaweed are chosen they deliberate until the conflict is solved. If the deliberation continues for more than one day the chief is responsible for the accommodations. The moment the solution is reached it must be documented and endorsed by the stamp of the chief".

Regarding the same problem of hakoura conflict, Abdella Ibrahim Teirab adds: ( The reason behind the existence of ajaweed comes from the fact that problems break out between families and tribes. those who have hakouras inherited from ancestors and those who haven't. Trees as boarder markers usually disappear therefore people often rely on the natural boundaries like mountains, ponds, and if there are no any people dig holes. The importance of digging these holes is that children must attend. When there is a conflict witnesses come and swear that they and $x$ and $z$ were there when this hole is buried and this land belong to $x$ or $z$. The verdict is then written and stamped to be used in future as document).

3.3.3 Conflicts on valley board farms: It is known that water runs in the sandy lands changes and shifts from time to another. Which causes conflicts on lands? Abdullah informs us that (regarding the conflicts of valley farms we see that the valley changes it's stream and people start to quarrel over the property of the land. The Ajaweed 
intervene to resolve the problem and define the boarders of each farm).

3.3.4 Leaving the land uncultivated for long time can cause problems when the owners come again to use it. Boarders may disappear. The ajaweed can intervene to solve the problem.

3.3.5 If animals graze in one's farm the farmer advises the owner of the animals not to let them repeat it.

3.3.6 If they do for the second time the farmer takes them to arrest concession (zaribat alhawami). Then the sheikh calls on the ajaweed to evaluate the damage. It is in the traditions that the value of the damage is divided into three. The farmer concedes a third and the owner of animals must pay the two-third. But generally, even these two-thirds are dispensed.

3.3.7 If the accident is repeated the case will be transferred to the native administration court which generally orders the owner of the animals to compensate the farmer and pay and amend to the court.

3.3.8 In case of damaging Arabic gum trees, the damage is evaluated by specialist and must be paid.

3.3.9 There is a rule to safeguard the rights of animal herders not to implicate in these troubles. It is known that village atounsphere which is one to two kilometers areas left around the village for grazing.

3.3.10 Concerning the efficiency of these customs in resolving conflicts between farmers and herders, Idris Albanay says (there are traditions which regulate the passage of the nomad herders from the ancient times. In the rainy seasons they must be in the northern part of Darfur and in summer they must go southwards up to Bahral-arab. This passage Murhal must be respected by all).

3.3.11 The traditions between nomads and sedentary are constituted by the following: before the arrival of the nomads to an area the chief must send representatives to that area's leader demanding the permission to enter and to stay for a short time. They must confirm their commitment to respect the traditions and customs of the area. Accepting the demand, a place will be allocated for camping and another area for grazing will be defined too. The local chief informs his subjects that Arab nomads are coming and they must be treated in a respectable manner.

If disagreements happen when livestock damage farmer unintentionally for example, the solutions follow three steps:

a) If the pastor is present, the farmer warns him and advises him to move away from his farm. He apologizes and leaves.

b) If the damage is big or the action is repeated, neighbors and ajaweed may be called from both parties to evaluate the damage and in most cases the farmer forgives.

c) If the ajaweed fail to solve the problem, the case may be tackled in a local court where the owner of the animal must compensate the damage. The informant continues: "there is always representative of the nazir or malik with the nomads to help them solve troubles with their wives, children, and neighbors. Concerning the rights of their movements, nomads generally meet after dinner to decide when and where to go. They send a messenger to look for place where water and grass are abundant. When they go and do not stay for long time in the same place in order to avoid overgraze. They leave a portion for their returning journey."

\subsection{The Rakoba}

Al- rakoba "the shelter" is a custom used in Darfur when there are material damages or deaths. When damage is caused to any family or clan by another, ajaweed sit to evaluate the damage and write it in a document. It is never paid. It's kept as a debt. When a member of this clan or family caused damages to that family it also put on the shelter (Fadoul,2008).

Al- rakouba as a traditional conflict resolution mechanism in Darfur is tightly related to the joudia. When the joudia is called for a session, they start investigating the two parties by listening to their testimonies then their witnesses. It worth mentioning here that any jouidia is composed of three delegations equals in number to represent the two parties and the neutral ajaweed. After the deliberations the ajaweed hold a close session then declare the verdict. Generally 
their judgment is accepted by both parties. The dimlij issues then a written document and finds the way to implement it. Idris Albanany says in this respect: (the dimlij and dowana are tribal leaders dominated by their tribes as spokes persons and the ones to represent the tribe in front of others. And Malik Rihemtalla adds (The dimlij is not appointed by the State. $\mathrm{He}$ is delegated by his tribe. His mandate is to guard the agreements with the other tribes as well as the traditions of his own tribe. The demlij has authorities more than the Shertai or the Omda. He has direct access even to the Sultan's home at any time).

Returning back to the Rakouba, when there is a conflict the damlij reviews the precedent incidents to see if there is a similar case. If he finds one, the case is then solved alternatively. If he does not, a new Rakouba will be established to be a reference for the probable coming cases.

An example of Rakouba and how it settles the conflict is the case of murder. If a murder takes place, people go back to see similar cases within the last ten years and it was solved similarly. This traditional practice is entirely acknowledged even by Sudanese national courts.

The tradition in such case is to give parties and the mediation time to deliberate about reducing the compensation decided by the ajaweed. When a final compromise verdict is reached, the dimlij must inform all demalij in Darfur and all demlijs of his own tribe throughout Sudan.

A basic concept to be mentioned regarding the Rakouba is the Monsas. The monsas is an agreement between two tribes to share indemnities and compensations (some sort of insurance). It helps the little clans and tribes to settle their duties within a frame work of big tribal alliance.

Later, many social, cultural, environmental and political changes reduced the efficiency of this mechanism to solve conflicts in Darfur. That is what we investigate in the coming chapter as well as the other mechanisms of peace building in Darfur.

\section{Peace Building Mechanisms}

\subsection{The social relations between the inhabitants of Darfur}

Darfur is a region of diversified social and cultural structures. The bigger part of its population is still rural. The features of the rural societies are obvious in the everyday life of the inhabitants of the region as the majority of the population practice agriculture, pastoralism, fishing, wood cutting and exotic fruit collection.

People of Darfur are very cooperative as all rural communities. We find the homogeneity and the importance of the extended family which constitute the nucleus of the clan which constitute in turn the nucleus of the tribe. As in the other rural areas of the world, the village or the camp constitute the individual's world that his activities rarely exceeds its social and geographical boundaries. Boys imitate fathers and girls imitate mothers. The most important value acquired in this community is that the individual must be voluntary and committed to satisfy the basic needs for welfare of the extended family. This social harmony appears in some of the social institutions like the Darra where people take the morning and evening meals together. Solidarity in the life cycle events is also shown in the Dara.

The farm lands constitute another opportunity for the inhabitance of the different villages to meet and create mutipple relationships.

In wedding ceremonies, for example, the work is divided. Some people go to collect wood, others bring water and another group builds a shelter for the new couple. The same happens in the death. Even if when one family receives aguest, all inhabitants of the village bring food and accompany the guest for some time as if he is the guest of all.

These relationships can include also cooperation in hostile or aggressive activities such as combating enemies. These activities are justified by the fact that people feel insecure in deserts and forests where starvations as well as wild animals threat human life. All these make individuals search a refuge in the tribe as it plays a decisive role in providing security in the areas inaccessible by the State. The ongoing conflicts and instability in Darfur could be interpreted as the Minimum requirement for defending the existence and the vital interests of the individuals and their tribes.

The people of Darfur, to adapt itself culturally in the context of linguistic, ethnic and cultural diversity, created institutions of integration like joudia, naffier, rakouba, fazza, massik, hunting campaigns etc. These people also produced cultural and social heritage that directly used as peace making and keeping mechanisms that are deeply rooted in the believe system of Darfurians like the following manifestations: 


\section{2 al- Nafier:}

It is a voluntary social and economic institution through which people achieve operations like: helping in farming, constructing houses, digging water sources as well as all other activities where an individual needs the help of others. It is to state that participation in the nafier is voluntary. Nothing is paid in exchange of labor. But in cases like natural disasters it becomes obligatory (Ibrahim,2004).

The Nafier in Darfur satisfy the human social and spiritual needs. The individual feels he is a constituent part of the community. It is practiced in Darfur from the remote past and transferred from generation to another up to the present with its entire heritage like: songs, dances and folk music used to encourage the participants (Haaland,.G.1977).

The Nafier has the ability to consolidate the pacific coexistence and peace building. It is made to shape the man of the area to produce what can absorb all internal and external influences and to affront all possible problems facing his life.

The Nafier as instrument for peace building:

- Insures the public participation in peace making, building and keeping

- Consolidates collective work.

- Could be used as voluntary system of peace building.

- Could be used to settle conflicts and keep the social security.

- Permits Peace culture to be defused through the accompanying folklore.

\subsection{Hunting Groups (al-ganis)}

Collective hunting trips are considered as one of the traditional mechanisms for peace building in Darfur. People gather after hearing the horn with their dogs and instruments to hunt. The hunting group is one of the most disciplined groups.

\section{4 al-Bramka Groups}

Baramka organizations are widely expanded in western Sudan among the Baggarra tribes in Kurdofan and Darfur. The Barmky distinguish himself in the society as being the most generous, courageous, cooperative and decent. He respects carefully the rules of politeness. He is always elegantly dressed. Their favorite drink of them is tea. They have rules for organizing sessions to drink it during which poems are recited. The individual Barmaky is called harif. There are other nicknames given according to the ranks, omda, nazir, ghafir.... A non- barmky is called, among the baramka, (kamkaly). The Baramka is a voluntary, educational and open membership institution working to help its members acquire the highest social values through organizing barmakka sessions. People join it to learn what helps them to become good members of the community.

\section{5 al-fazza}

It means lending someone a hand when he needs help to avoid a danger. When life stock for example, is robbed or lost, villagers go to look after it. It starts with a horn sound announcing the event. All people who are able to hold arms are supposed to participate without exceptions (Ibrahim,2007).

The participants are divided into two groups; the first one (alkassib) the brave fighters on their horse or camels' backs follow the traces. The other group (alaagib) trace back from where the thieves come. Where ever they pass by a village, the inhabitants must provide them with food and water and some of them accompany the campaign. If they find the livestock they come back in carnival through all villages where they are warmly welcome and generously hosted. If they do not, they just describe the lost animals to whoever they meet fixing a prize to the one who gives any information about them. During the campaign, participants recite (doubate) and encouragement songs. The traditions in Darfur impose penalties by the (ageed) on those who do not participate. Informants of the research area enormously stated that the insistence on participating in the (fazza) reflects the fatal effects that attacks of other groups can cause to the tribe.

\section{6 al-darra}

Al-darra is a place where the inhabitants of the village meet to have morning and evening meals as well as Ramadan breakfast. It is always located in front of the house of the village elder or in front of or inside the massik. In the bigger 
villages it is possible to find more than one darra. Its importance comes from the point that it constitutes a social solidarity, institutions and a place for exchanging news and daily life matters.

\subsection{Local markets}

There are two types of markets in Darfur. Bigger markets where people gather from remote areas and local ones distributed between villages to provide materials of everyday consumptions. They are generally distributed and held on one week day; Sunday market, Monday market, for example. It constitutes a social link between the inhabitants in addition to selling and buying. The market is also a place for the traditional court of justices and other social transactions.

\subsection{Life cycle events}

The Darfurian cultural consciousness is full of principles that encourage individuals to live in peace with others. If we trace the life of an individual from the family to the big society, we find that in Darfur, children are born in the hands of a mid-wife called at any time to provide humanitarian service for free. What she receives from the parents of the newly born is a gift not a wage. Then, the child is guarded by all the surrounding individuals until he grows to the age of circumcision or excision which is also done for free. When children are circumcised, their colleagues and mates collect hens from throughout the village not necessary from relatives or friends until the circumcised are cured.

Playground provides also a good chance for children to play collective games where today's mates can become tomorrow's contestants.

The child then migrates to become a disciple of one of the sheihks who also offer instructions for free. The accommodation of these disciplines is provided by the inhabitants around the massik. When he reaches certain oversets (sharaffa) the neighboring community offer him gifts and celebrates the occasion.

Marriage in Darfur is not only a family business. The family receives material support from neighbors and friends to meet the expenses of the wedding ceremony. In these ceremonies women prepare food and men build a house for the couple. These events are accompanied by dances and songs performed collectively and freely. This cooperative life continues until the one is dead where all people gather to bury him.

Man in Darfur cannot produce all his life needs alone. He is always assisted by others who share experience, knowledge and labor with him. That is one of effective mechanisms for peace building in Darfur.

\subsection{Folk literature}

The social and cultural structure of Darfur has influenced the popular literature. The continuous changes and the multitudes of ethnic origins and languages enabled the various groups to produce a rich literature that could be used in peace building.

As an example, we can mention al-haday who is a traditional poet among the Arabs groups of Darfur and the falatta in particular. He composes poems to praise or insult people or horses. He also acts as guardian of the heritage and political support to the power of the tribe.

The popular poet works to reflect the image of the tribe. He praises the heroes and history of the tribe and the brave warriors, confirms the pure Arabic descent of the tribe as well as the noble origin of their animals too. The non Arabic groups as the fur do the same in their frengabia. They sing the bravery, strength and cavalry values. The hakama plays a dominant role here. She incites the men to fight bravely. She also sings the defects of the others.

Proverbs in turn reflect the image of self and the others. In Darfur there are proverbs supporting the pacific coexistence and others call for the contrary. Most of these proverbs are used in discussions to settle conflicts.

\section{Conclusion}

Social interaction between the components of Darfur remained active peacefully as long as these mechanisms remain active. Availability of natural resources and native administration were key factors for the sustainability of peaceful coexistence. Natural, social and political changes caused drastic changes that affected directly in the relationships between the inhabitants which resulted in conflicts between small groups at the beginning of development to conclude major ones through ethnic support. Ethnicity is still deep in these ethnic groups.

The traditional tools fell behind to solve the ever developing conflicts. In fact these mechanisms were expected to 
be weakened by the intervention of the central government in its orientation. The situation is utterly worsened by the abolition of the native administration; the late reformation of the native administration was based on hands on these who enjoy upper hand in the central government. None theses the government have created new administrative units for groups which were historically not recognized in the conformity of the traditional administration mechanisms. The government decrees only widened the conflicts and escalated polarization among the ethnic opponents. Generally it is worth mentioning that different conditions accelerated competition among many different ethnicities and in tensed other small disputes which would have been settled tribal leaders were empowered, through traditional mechanisms. Hence it looks vital that these mechanisms are still needed to settle the complicated problems of Darfur.

\section{References}

Isam M. Ibrahim, Utilization of Group Work (Nafeer) in Social Development of Sudanese Communities, Unpublished Ph.D. Thesis, elNileen University, 2004.

Isam M. Ibrahim, "Reduction of Conflicts between Farmers and Pasturalists around Natural Resources", Research Project, Oxfam. 2002. Isam M. Ibrahim, "Self-Image and Otherness: Darfurian oral literature as sources for conflict", Journal of Darfurian Studies, Washington, 2006.

G.D. Lompen. "History of Darfur", Sudan Notes and Records, Vol. 31, Part 2, 1950.i

Haaland G., "Nomdism as Economic Career among Seedententries of the Sudan Savannah Belt", in Can Cunnison and Wendy James (ed), Essays in Sudan Ethnography (14). Hurst and Company London 1977.

Browne, W.G., Travels in Africa, Egypt and Syria: 1792-1799, London.

Abdoulaye Bathily 1977 : Traits fondamentaux de l'Etat au Soudan occidental et central au moyen âge (8e -16 siecle) in Yusuf Fadl Hassan and Paul Doornbos (ed), The Central Bilad Al-Sudan, Tradition and Adaptation, pp. 161-171.

R.S. O'Fahey 1977: "Land and Privileges in Dar Fur", in Yusuf Fadl Hassan and Paul Doornbos (ed), The Central Bilad Al-Sudan, Tradition and Adaptation, pp. 262-283.

A.P.G. Michel More, Sudan Notes and Records, 1932 Vol. 15 Part 2.

G. Ayoub Balamoan, 1981: Peoples and Economics in the Sudan 1884-1956, Harvard University Center for Population Studies.i

A.C. Beaton, "The Fur", Sudan Notes and Records, Vol. 29, part 2, 1948. 